\title{
CONCEPT OF FEMALE DORMITORY BEDROOMS BASED ON STUDENTS' PREFERENCE AND ADAPTATION
}

\section{Case Study: Type B Non-Affiliated Organization Pesantren}

\author{
Mimin Aminah Yusuf*, Arina Hayati**, Muhammad Faqih** \\ *) Master Student, Department of Architecture, Faculty of Architecture, Design, and \\ Planning, Institute of Technology Sepuluh Nopember, Indonesia \\ **) Lecturer, Department of Architecture, Faculty of Architecture, Design, and \\ Planning, Institute of Technology Sepuluh Nopember, Indonesia \\ e-mail: miminaminahyusuf@gmail.com
}

\begin{abstract}
In Indonesia, Pesantren is a private boarding school managed by an organizational or non-organizational Islamic institution. The Pesantren's buildings are commonly not well designed and its design represents the institution's requirements. This paper investigates the bedroom design of dormitory based on student's preferences and adaptation, which then will be used as a design's concept reference. Bedroom is the smallest scale of built environment, yet it has great influence on accommodating users' daily needs. Moreover, the bedroom dimension especially for a pesantren's dormitory has limited area but with high occupant density. This study uses a case study strategy supported by quantitative and qualitative methods. Six Pesantrens are chosen to find bedrooms' typology by observation. Next, the typology is tested to 500 respondents in Sunan Drajat Pesantren by using a questionnaire. Quantitative analysis is employed to find the students' preferences, and afterwards the student's adaptation is investigated. The result shows that the bedrooms' typology in pesantren's dormitory do not meet the minimum standard of bedroom 's design. The typology is based on observation in six Pesantren's bedrooms. The study also reveals that student's preference for bedroom's dormitory is influenced by physiological and psychological aspects. Physiological aspects indicate thermal and visual comfort. The psychological aspects are motivation, security, privacy, personal space, territory, crowding and density. The bedroom size, number of occupants and bedroom area per person do not meet students' preference, consequently the adaptation process is difficult. The types of adaptation are by reaction, by adjustment and by withdrawal. The design concepts propose from the bedroom's dimension (bedroom area per person is $2.8 \mathrm{~m}^{2}$ ), the students' belonging and furniture arrangement, use space, number of occupants (small, small-medium, medium, large, and extra-large bedroom).
\end{abstract}

Keywords: Bedroom, Dormitory, Pesantren, Preference, Adaptation 


\section{INTRODUCTION}

Human and environment have mutually relationships to improve the quality of life (Sudiarta, 2016). When the environment cannot accommodate human needs, they will do enviromental adaption based on preferences. The higher level of suitability environment and preferences are needed, the lower adaptation efforts are undertaken (Rapoport, 2005).

In Indonesia, Pesantrens are Islamic private boarding school which mostly are not well designed and less comfortable with high density of occupant (Bosworth, et al, 1995). The environment of pesantren usually does not accommodate the student needs and has low environmental maintenance (Khajehzadeh and Vale, 2014). Therefore, pesantren has a slum image from general perspective (Husaini in Suryawan, 2013; Badri, 2008; Ministry of Health, 2007; Sopi'i, 2014; agtvnews.com, 2017; and portal.banyuwangikab.go.id, 2013).

In Indonesia, there are three types of Pesantren based on its infrastructure and facilities, namely Type A, B and C. This paper highlights pesantren's type B which has students' dormitory and formal school system (Ministry of Religion in Miftahuddin, 2011); yet, the facilities has insufficient condition to accommodate the students' daily needs (Mu'in, et al, 2005). Moreover, the type of non-affiliated organization pesantrens are organized and developed without well design concept of dormitories (Wahid, 2001).

Amole (2009) has suggested four environmental levels that can be observed in dormitory's environment. Those are levels of dormitory's environment, dormitory building, a floor's plan, and its bedroom. This study investigates the smallest environment which is the dormitory's bedrooms in Pesantren. Dormitory's bedroom is the most important place for students' daily activities and has various environmental adaptation (Azzahro, 2017). Moreover, since the dormitories usually have higher occupant density, the environmental conditions are less adequate and diseases can be spread round the dormitory very quickly such as scabies (Badri, 2007; Fernawan, 2008). Therefore, formulating dormitory's design concept is necessary to improve the quality of life in pesantren based on student's preference and adaptation. Further, this study is conducted in female dormitories which indicates higher adaptation level than in male dormitories (Hidayat, 2009).

\section{THEORY / RESEARCH METHODS}

The literature review explains pesantren overviews, theory about bedroom as the smallest level of the built environment and the process of human evaluation of the environment, preference and adaptation.

\section{Pesantren in Indonesia}

Pesantren is an Islamic education institution with a dormitory system. The student learns religious education from kiai/ caregiver (Arifin, 2010). There are five forming elements in pesantren which are kiai/caregiver, mosque, dormitory, student (santri), 
and religion book/ kitab kuning (Dhofier, 1994). According to Ministry of Religion (Miftahudin, 2011), there are three types of pesantrens based on education system, which are type A (has student dormitory, classically educational system, no formal education, and no curriculum standard); type B (has student dormitory, integrated with formal school with curriculum standard); and type $\mathrm{C}$ (has student dormitory with separated formal schools which is outside the pesantren and curriculum is decided by the kiai). Furthermore, pesantren is also divided based on its organization, which are affiliated organization and non-affiliated organization (private or family ownership) pesantrens.

\section{Bedroom Level}

According to Chiara and Callender (1987), several design aspects of dormitory's bedroom are considered, include:

\section{a. Bedroom Dimension}

Bedroom's dimension considers (a) furniture size and design, (b) furniture use space/ minimum space required for furniture (figure 1), and (c) the combination of furniture items.

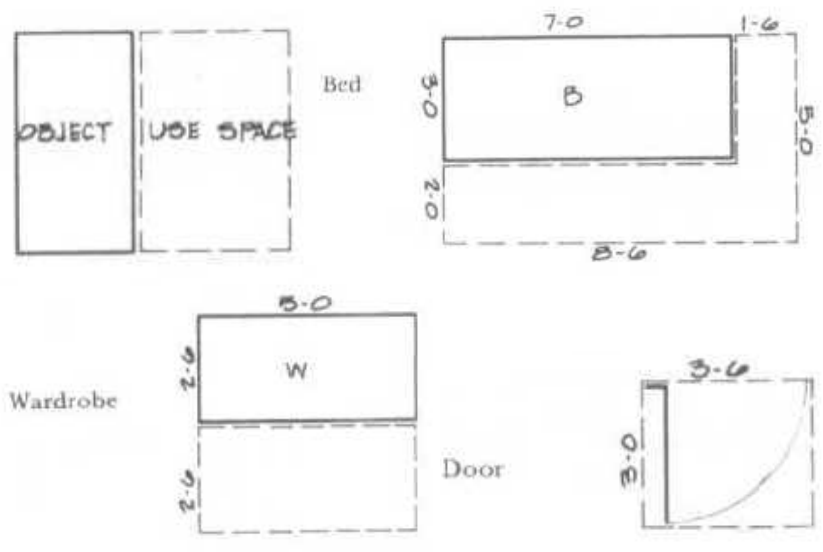

Figure 1. The Use Space of Furniture Source: Chiara and Callender, 1987

\section{b. Bedroom Size}

According to Chiara and Callender (1987), the bedroom size and shape are influenced by two aspects of possible room change: adaptability of furniture arrangement and divisibility of space. There are several typologies of bedroom size based on its use space (Chiara and Callender, 1987), which are (a) minimum type (accommodates required furniture with the overlapping use space); (b) optimum type (no overlapping furniture and use spaces); (c) Generous (with space divisibility). (Figure 2) 


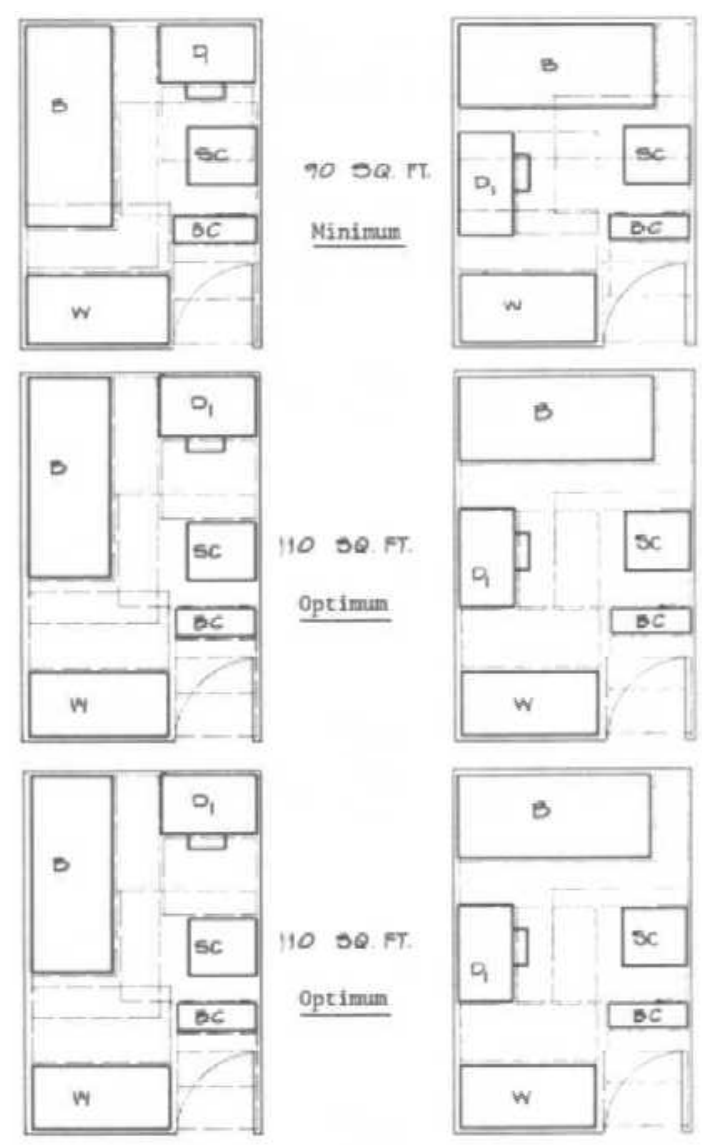

Figure 2. Bedroom Typology Based on Use Space Source: Chiara and Callender, 1987

\section{c. Number of Occupants}

Based on the number of occupants (Chiara and Callender, 1987), types of bedrooms are single bedrooms, split double bedrooms, double bedroom, triple bedroom, fourstudent bedroom. While GPPPBM in Wulandari (2016) said that the number of occupant in dormitory is 8-12 people.

\section{Human Evaluation Process to the Environment}

Rapoport (2005) explains that the built environment is a designed environment that has organization of space, time, communication/the meaning of the space, system of settings, cultural landscape, and made up of fixed, semi-fixed and non-fixed features. The process evalution to environment starts environmental filter and percieves through personal experiences and cultural variables such as attitude, value, need, ideal, image, standart, and etc. Next, they evaluate and respond the conditions based on their preferences and adaptation (figure 3 ). 


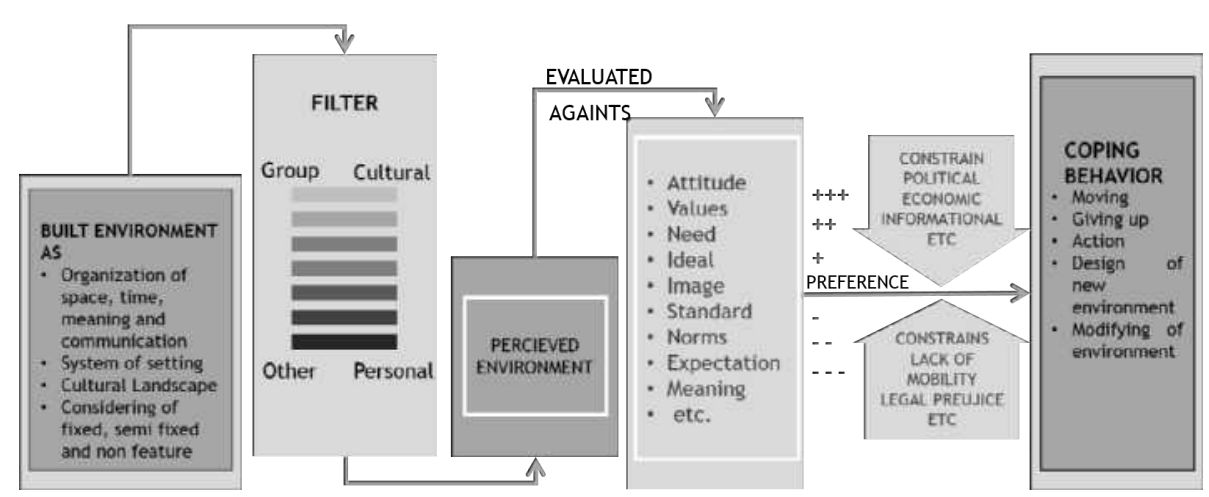

Figure 3. Human Evaluation Process Source: Rapoport, 2005

\section{Preference in Architecture}

According to Rapoport (2005), preference involves choice and design to environmental quality which is evaluated through several of the components of culture (Figure 3). Preferences are closely related to occupancy perceptions (Rapoport, 2005), behavioural, responses and decision-making on multiple options (Triyuli, 2005). Perception has an important role to human mindsets when choosing domestic environment influenced by the meaning of previous occupancy (Arias, 1993). There are three mechanisms in preference (figure 4) according to Arias (1993):

a. Residential setting analysis. This stage identified the need on designed objects. The influenced aspects are demographics, psychographic and physical design attributes (furniture, etc).

b. Design Impact Analysis. This stage organizes space and proposes alternative design/ typology.

c. Preference Analysis. After passing the two processes, the typology of environment will be selected. The choice of typology is influenced by human attitude, values, and need.

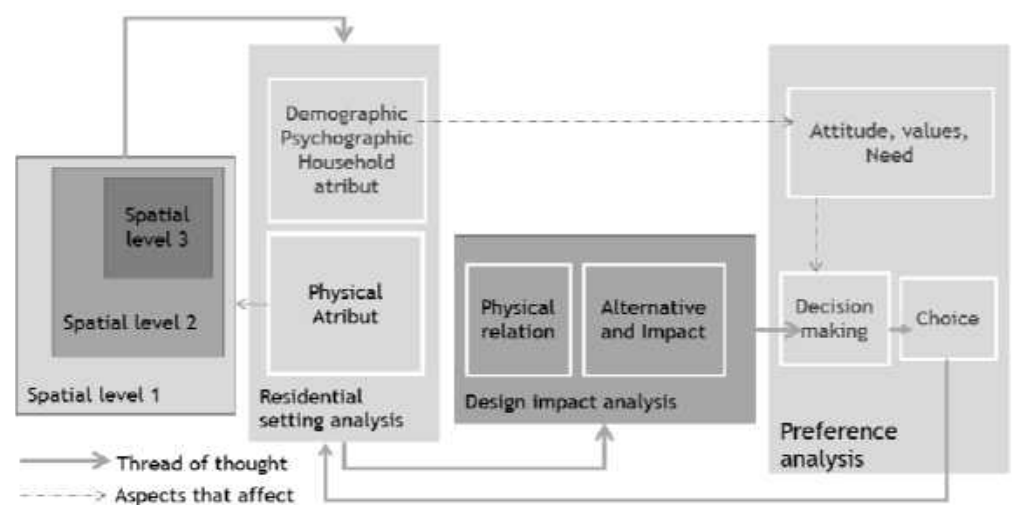

Figure 4. Mechanism of Preference Source: Arias, 1993 


\section{Adaptation in Architecture}

People formulate the environmental adaptation when thus the environment cannot meet human preference. Adaptation is an activity pattern created when people live in new environment (Tuan 2001 in Meliala, 2013). According to Rapoport (2005), the efforts or coping behaviours are made to adapt the new environment by (a) modifying the environment; (b) designing new environment; (c) changing behaviour; (d) action; (e) giving up; and (f) moving.

Berry (1980) identifies three types of adaptation, which are (a) by reaction (changing behaviour to reduce conflict with environment); (b) by adjustment (changing the environment that is appropriate to desired environmental conditions); and (c) by withdrawal (letting and moving to desired environment). Rapoport (2005) suggests another type of adaption by giving up (surrender), beside three types of adaptation suggested by Berry (1980).

\section{Methods}

This research uses combine strategies which are case study, quantitative and qualitative research. The research has four stages; first, choosing six pesantrens that all represent the type B non-affiliated organization pesantren with similar tuition fee without master plan dormitory design. The Six pesantrens are Sunan Drajat pesantren (PPSD) Lamongan, Matho'liul Anwar pesantren (PPMA) Lamongan, Tarbiyatut Tholabah pesantren (PPTT) Lamongan, Khoiriyah Hasyim pesantren (PPKH) Jombang, Walisongo pesantren (PPPW) Jombang, and Darul Ulum pesantren (PPDU) Jombang. By exploring six pesantrens through documents, interview and observasion, bedrooms' typology has been identified and used as questioner's variables.

Second, after the aspects of bedroom typology are determined, the variables are tested through questionnaires only in female dormitory of Sunan Drajat pesantren (PPSD). Respondents are 500 students that was chosen by random sampling technique. PPSD's female students are chosen as respondent because the PPSD has various form of education stage with the highest number of student from different regions. The questionnaire uses Likert scale and analysed using cross-tabulation. After student's preference is known, the level of satisfaction is known, then environmental adaptation can be identified using in-depth interview and observation as tactics. Lastly, the concept of bedroom is formulated based on students' preference and adaptation (figure 5). 


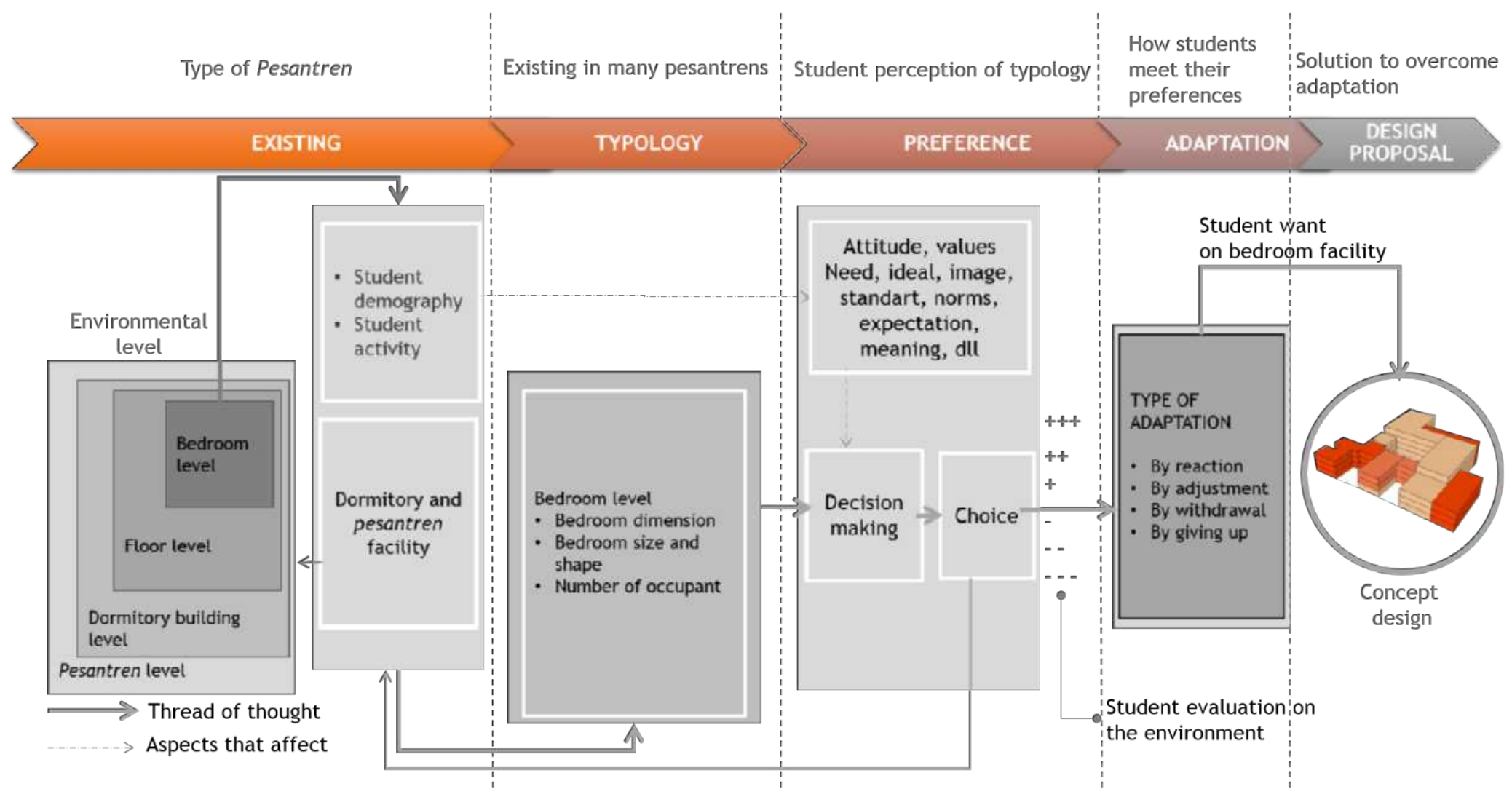

Figure 5. The Development Theory of Preference and Adaptation in Pesantren Context Source: Developed from Arias, 1993; Berry, 1980 and Rapoport, 2005 


\section{RESULTS AND DISCUSSION}

The discussion is presented from explaining the pesantren's activities, typology, preference and adaptation to proposing the design concept.

\section{The Activity of Pesantren Bedroom}

From the observation, the characteristic of bedroom in pesantren type $\mathrm{B}$ has compound function. It means that students use the bedroom for several activities, such as doing domestic activities and worshiping, also studying. Because of high density, occupancy in limited space, student tend to perfom their activities in several places inside or outside dormitory's area. For example, learning activity which is ideally done inside the bedroom, they often study outside their room or other places which is more comfortable and less dense.

\section{Bedroom Typology}

Determining the bedroom typology is aimed to formulate variables for research questionnaire. Aspects of bedroom typology are bedroom dimensions (furniture and its use space), bedroom size and the number of occupants (Chiara and Callender, 1987). To simplify the analysis, the discussion is explained from the elements of furniture for student's belongings, bedroom size, bedroom area per person, and type and number of occupants.

\section{a. Furniture and Students' Belongings}

According to Chiara and Callender (1987), furniture in the dormitory's bedroom are mattresses, cupboards, tables, chairs and doors. The furnitures in pesantren's bedroom are only the cupboard and door. In pesantren, some students' belongings are identified and used comunally, such as clothes hangers, shoes rack, bath-tool rack and trash bin. Students' belongings are folding mattresses, carpets, pillows and bolsters, buckets, bags, dishes or baskets, mukena, clothes, books and the Qur'an, stationery, cosmetics and medicine.

Associated with the furniture placement, there are two types of bedrooms. The type A (figure 6) is where all the students' belongings are organized inside the bedroom both of which are clean, dirty, sacred, unclean, wet and dry. This organization is only applied in PPSD, partly in PPMA and PPDU. The type B (figure 7) indicates that all dirty, wet and unclean students' belonging are placed outside the bedroom. This type can be seen in, PPTT, PPKH, PPPW, and partly in PPMA and PPDU. 

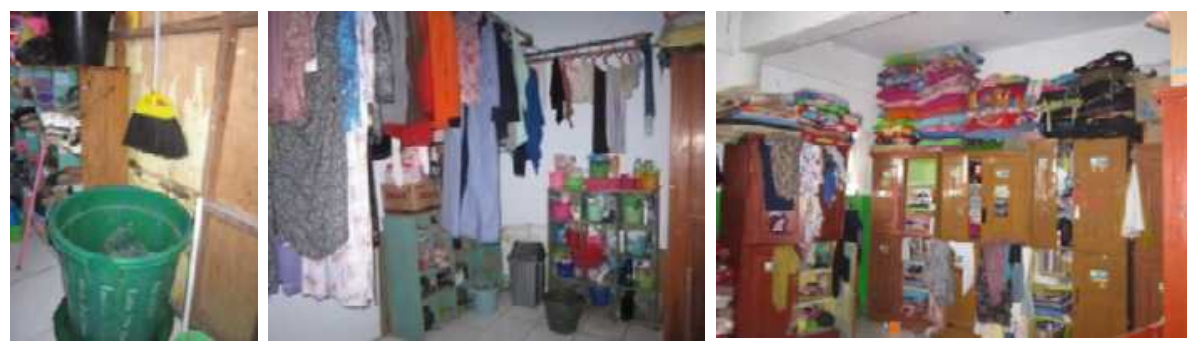

Figure 6. Type A of Furniture Placement

Source: Author documentation, 2018

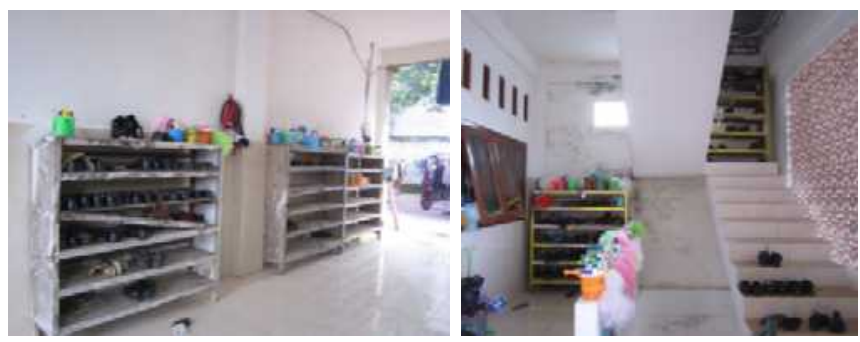

Figure 7. Type B of Furniture Placement

Source: Author Documentation, 2018

There are two types of interior arrangement in type A bedrooms, which are (a) type 1, in which clean and dirty stuff is separated and placed in different space (Figure 8), and (b) type 2, which has no separation space for clean and dirty stuff (figure 9).

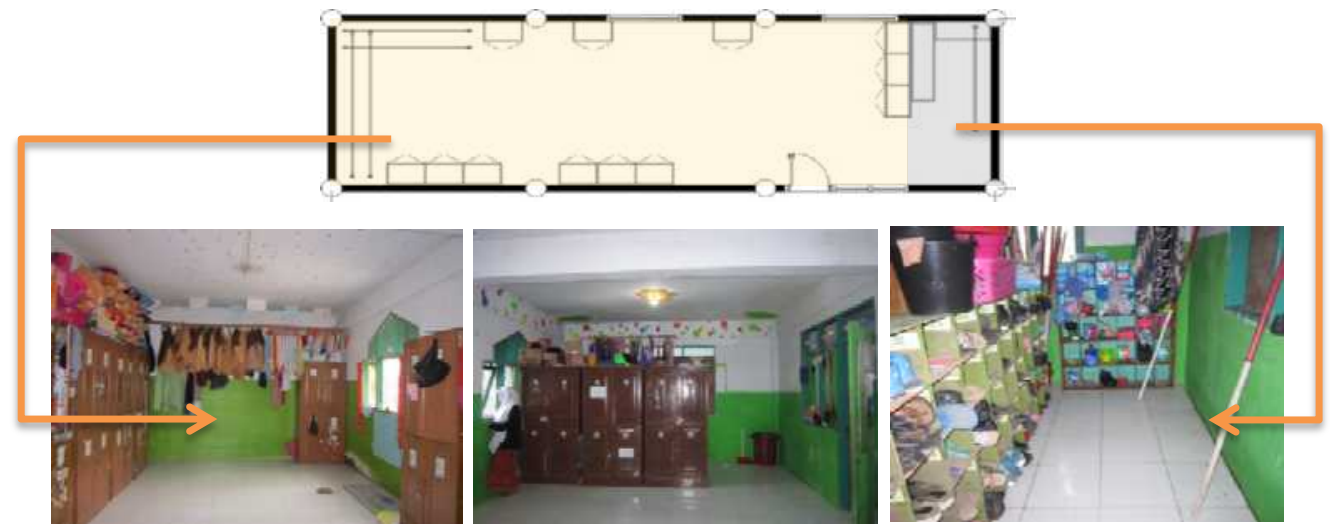

Figure 8. Bedroom Type 1 of Interior Arrangement Source: Author Documentation, 2018 


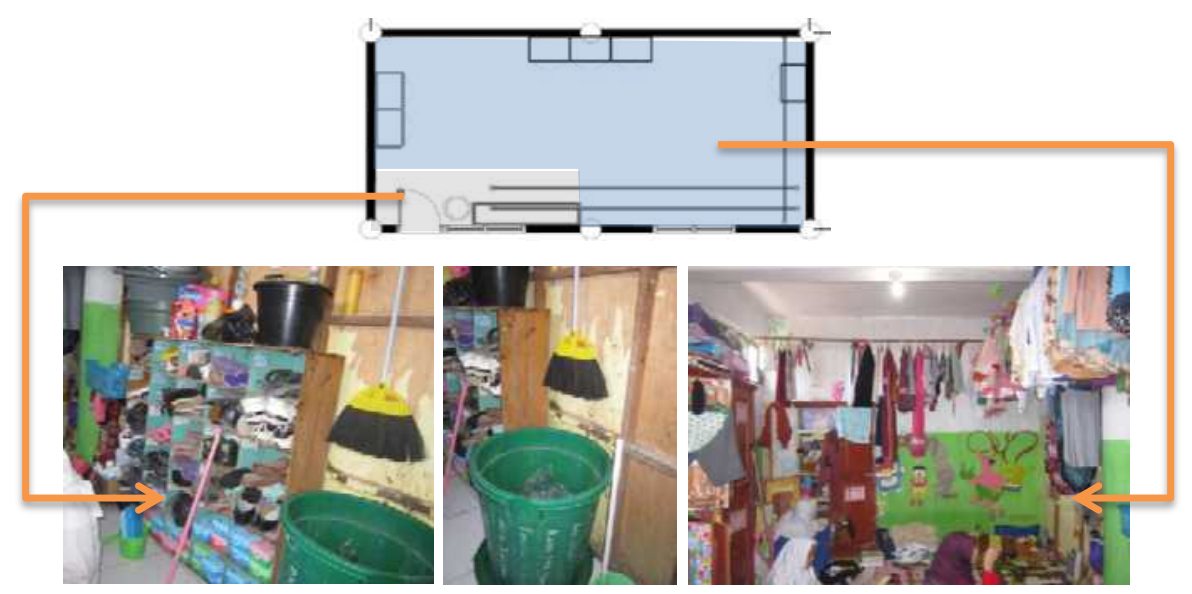

Figure 9. Bedroom Type 2 of Interior Arrangement Source: Author Documentation, 2018

\section{b. Bedroom size}

Bedroom size is influenced by the adaptability and divisibility of the bedroom (Chiara and Callender, 1980). The variation of adaptability and divisibility of bedroom gives the users flexible decision to move and to adjust the bedroom's furniture in accordance with their needs (High and Sundstrom, 1977). In the context of pesantren bedroom, in six pesantrens have high density of occupants and crowded condition, thus the flexibility of bedroom is low (table 1).

Table 1. Bedroom Dimension and Number of Occupants

\begin{tabular}{|c|c|c|c|c|c|c|c|}
\hline Pesantren & $\begin{array}{l}\text { Bedroom } \\
\text { dimension }\end{array}$ & $\begin{array}{c}\text { Room } \\
\text { wide }\end{array}$ & $\begin{array}{c}\text { Number } \\
\text { of } \\
\text { occupant }\end{array}$ & $\begin{array}{l}\text { Area/ } \\
\text { person }\end{array}$ & $\begin{array}{c}\text { Standard } \\
\text { (per } \\
\text { person) }\end{array}$ & Feasibility & $\begin{array}{c}\text { Bedroom } \\
\text { type }\end{array}$ \\
\hline \multirow{4}{*}{ PPSD } & $8 \times 8 \mathrm{~m}$ & $64 \mathrm{~m}^{2}$ & $40-50$ & $1.5 \mathrm{~m}^{2}$ & $4 \mathrm{~m}^{2}$ & Not feasible & - \\
\hline & $12 \times 4 \mathrm{~m}$ & $48 \mathrm{~m}^{2}$ & $30-36$ & $1.5 \mathrm{~m}^{2}$ & $4 m^{2}$ & Not feasible & - \\
\hline & $8 \times 4 \mathrm{~m}$ & $24 \mathrm{~m}^{2}$ & $20-25$ & $1.2 \mathrm{~m}^{2}$ & $4 m^{2}$ & Not feasible & - \\
\hline & $4 \times 4 \mathrm{~m}$ & $16 \mathrm{~m}^{2}$ & $8-12$ & $1.6 \mathrm{~m}^{2}$ & $4 m^{2}$ & Not feasible & - \\
\hline \multirow[t]{3}{*}{ PPMA } & $3 \times 3 \mathrm{~m}$ & $9 \mathrm{~m}^{2}$ & $4-8$ & $1.5 \mathrm{~m}^{2}$ & $4 m^{2}$ & Not feasible & - \\
\hline & $5 \times 5 \mathrm{~m}$ & $25 \mathrm{~m}^{2}$ & 20 & $1.25 \mathrm{~m}^{2}$ & $4 m^{2}$ & Not feasible & - \\
\hline & $12 \times 7 \mathrm{~m}$ & $84 \mathrm{~m}^{2}$ & 36 & $2.3 \mathrm{~m}^{2}$ & $4 m^{2}$ & Not feasible & Minimum \\
\hline \multirow[t]{2}{*}{ PPTT } & $7 \times 5 \mathrm{~m}$ & $35 \mathrm{~m}^{2}$ & 20 & $1.75 \mathrm{~m}^{2}$ & $4 m^{2}$ & Not feasible & - \\
\hline & $6 \times 5 \mathrm{~m}$ & $30 \mathrm{~m}^{2}$ & 18 & $1.6 \mathrm{~m}^{2}$ & $4 m^{2}$ & Not feasible & - \\
\hline \multirow[t]{2}{*}{ PPKH } & $7 \times 8 \mathrm{~m}$ & $56 \mathrm{~m}^{2}$ & 20 & $2.8 \mathrm{~m}^{2}$ & $4 m^{2}$ & Not feasible & Minimum \\
\hline & $5 \times 6 \mathrm{~m}$ & $30 \mathrm{~m}^{2}$ & 12 & $2.5 \mathrm{~m}^{2}$ & $4 m^{2}$ & Not feasible & Minimum \\
\hline \multirow[t]{2}{*}{ PPPW } & $7.5 \times 6 \mathrm{~m}$ & $45 \mathrm{~m}^{2}$ & 20 & $2.25 \mathrm{~m}^{2}$ & $4 m^{2}$ & Not feasible & Minimum \\
\hline & $15 \times 7 \mathrm{~m}$ & $105 \mathrm{~m}^{2}$ & 50 & $2.1 \mathrm{~m}^{2}$ & $4 m^{2}$ & Not feasible & Minimum \\
\hline \multirow[t]{2}{*}{ PPDU } & $6 \times 10$ m & $60 \mathrm{~m}^{2}$ & $22-25$ & $2.5 \mathrm{~m}^{2}$ & $4 m^{2}$ & Not feasible & Minimum \\
\hline & $7 \times 6 \mathrm{~m}$ & $42 \mathrm{~m}^{2}$ & 23 & $1.8 \mathrm{~m}^{2}$ & $4 m^{2}$ & Not feasible & - \\
\hline
\end{tabular}

Table 1 shows that there are several types of bedroom size. For questionnaire, the typology of bedroom size is classified to four classifications; which are small, 
medium, large, and extra-large bedroom (table 2). The following are aspects of the bedroom typology.

Table 2. Bedroom Size Typology in Pesantren

\begin{tabular}{ccc}
\hline Bedroom type & Dimension & Wide \\
\hline Small & $3 \times 3 \mathrm{~m}$ & $9 \mathrm{~m}^{2}$ \\
& $4 \times 4 \mathrm{~m}$ & $16 \mathrm{~m}^{2}$ \\
Medium & $5 \times 5 \mathrm{~m}$ & $25 \mathrm{~m}^{2}$ \\
& $6 \times 6 \mathrm{~m}$ & $36 \mathrm{~m}^{2}$ \\
Large & $7 \times 7 \mathrm{~m}$ & $49 \mathrm{~m}^{2}$ \\
& $8 \times 8 \mathrm{~m}$ & $64 \mathrm{~m}^{2}$ \\
Extra-large & $9 \times 9 \mathrm{~m}$ & $81 \mathrm{~m}^{2}$ \\
& $10 \times 10 \mathrm{~m}$ & $100 \mathrm{~m}^{2}$ \\
\hline
\end{tabular}

Source: Author Analysis, 2018

\section{c. Bedroom Area per Person}

According to the standard in The Architect's Handbook, the minimum bedroom size per person is $4 \mathrm{~m}^{2}$ (Hamdi, 2016). In all six pesantrens dormitories, the bedroom size does not meet the minimum standard. Table 1 indicates that bedroom area per person is obtained from $1.2 \mathrm{~m}^{2}$ to $2.8 \mathrm{~m}^{2}$. Moreover, from field observation has found that all bedrooms have less dimension from the minimum standard according to Chiara and Callender (1980). This condition shows that the space dimension cannot accommodate the student's goods and furniture. For example, in PPSD and PPMA, sleeping activities cannot be accommodated with mattresses, therefore students prefer to sleep outside bedroom (i.e. in the corridor).

\section{d. Type and Number of Occupants}

Based on observation analysis, the number of occupants are classified into five types, (a) 4-10 people; (b) 11-20 persons; (c) 21-30 persons; (d) 31-40 persons; and (e) 40-50 persons. This condition does not meet the minimum requirement stated by Chiara and Callender (1980). Yet, the type (a) meet the standard from GPPPBM in Wulandari (2016).

In addition, the member of occupant in each bedroom is also determined by the level of school (PPSD), grade level (PPSD, PPKH, PPDU, PPPW and PPTT), majors/level of education (PPMA and PPTT), interest such as language (English or Arabic) or memorizing Al-Qur'an (PPMA, PPSD and PPPW) and mixture (PPMA and PPTT).

\section{Students' Preference and Adaptation}

The discussion of preference and adaptation analysis, starts location and student demography description in the PPSD, then analysis on aspects of bedroom facility is described.

\section{a. Existing and Demography of PPSD}

Sunan Drajat pesantren (PPSD) is in Banjaranyar Paciran Lamongan East Java 
Indonesia. This pesantren is one of pesantrens influenced by walisongo. PPSD has formal school levels, from kindergarten to college. Type of dormitory building is connected dormitory with 3-4 floors (Figure 10) (Yusuf, 2018).

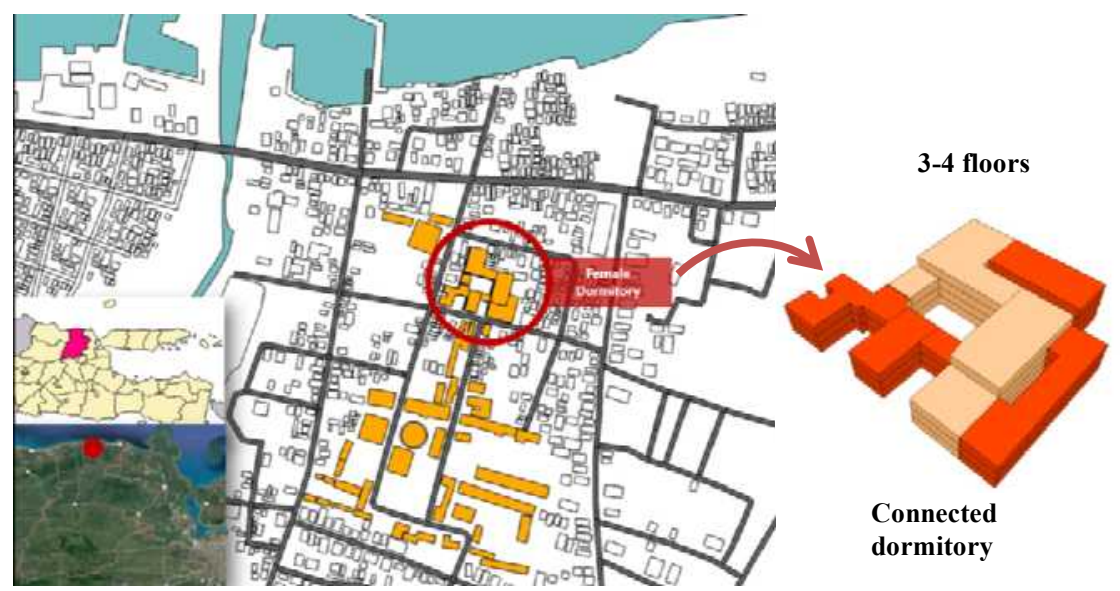

Figure 10. Location of PPSD Source: Author, 2018
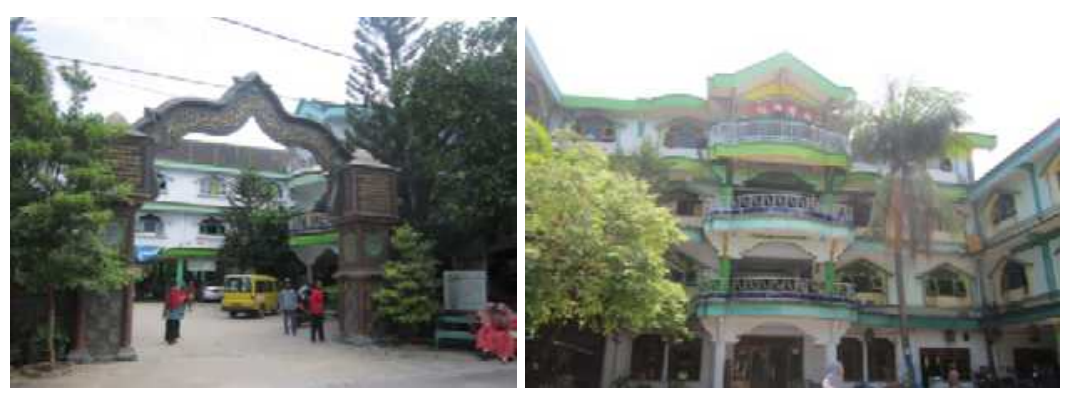

Figure 11. Female Dormitory Condition in PPSD Source: Author Documentation, 2018

The total female population in PPSD is 2090 students. In junior and senior high school level are 1897 students. The research's sample are 500 respondents who are in junior high school level (44\%) and in high school (56\%). The respondents are selected based on level of education because they have similar education program and activities in the pesantren. Based on data analysis, the details of grade level of respondents are class VII (5\%), VIII (27\%), IX (12\%), X (24\%), XI (8\%), and XII $(24 \%)$. Duration of years of compulsory education are one-year student $(15 \%)$; two years $(27 \%)$; three years $(40 \%)$; four years $(12 \%)$; five years $(3 \%)$; and six years $(3 \%)$.

\section{b. Furniture and Students' Belongings}

In order to follow the pesantren's values of living with simplicity, the students only bring specific and limited belongings. From the interviews, the students prefer to 
bring more individual stuffs and belongings, yet the regulation is very strict. Consequently, the adaptation effort is done by giving up or doing adjustment on placement of furniture, students' belonging and space arrangement.

From the analysis shows that the students agree that all their belongings are placed inside the bedroom (76\%). The students prefer to keep their belongings inside the bedroom due to lack of privacy and security. Since in PPSD allows students to keep their belongings inside the bedroom, the level of students' satisfaction is high accordance with student's preference. Despite of crowding and limited space in dormitory's bedroom, some adaptation is performed by students to accommodate their needs. The adaptation effort is by doing several adjustments; for example, labelling their belongings (figure 12), determining their space territory, and so on.
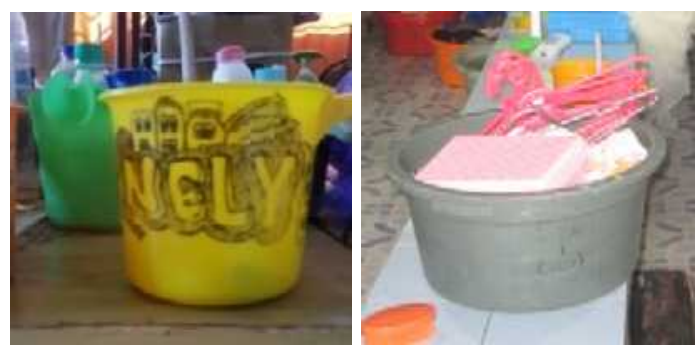

Figure 12. Labelling of Students' Belonging Source: Author Documentation, 2018

In PPSD, students choose interior arrangement of type 1 (Figure 8) which the clean and dirty area are divided. Students feel more comfortable when there is space separation between area for clean and dirty stuffs. Moreover, the clean area is ideal for worshipping/praying activity. The bedroom arrangement is also influenced by the position of door and window. Door position (Figure 13a and 13b) provides more opportunities to place students' belongings. The window position also affects the arrangement of cupboard placement. Students tend to avoid putting a cupboard in front of a window if the window is only at height of one meter above floor.

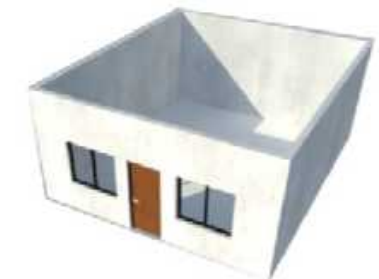

(a) The Middle Position

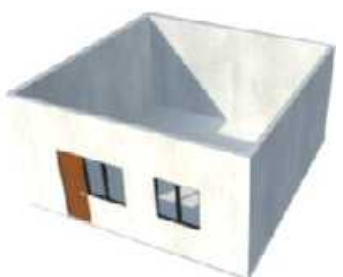

(b) The Side Position (There is still Space)

Figure 13. Position of Door Source: Author, 2018

PPSD has total of 76 bedrooms occupied by junior and senior high school students. From 76 bedrooms, 31 bedrooms is classified as Type 1 (Figure 8) and the other bedrooms are as Type 2 (Figure 9). From dependency analysis shows that 
students who occupy bedrooms Type 1 are more satisfied and meet their preference than bedrooms Type 2. Adaptation by reaction is performed in Type 2 than in Type 1. For example, group regulations both proposed by students or the pesantren are applied to create comfortable condition both personally and generally, i.e. regulation for cleanliness rule and students' belonging arrangement.

\section{c. Bedroom Dimension/Size and Number of Occupants}

The bedroom dimension corresponds to the number of occupants, thus is known by how many bedroom areas per person is favoured by students. Psychological aspect of personal space is also influenced which preferred room dimension is chosen by the students. The denser of occupier density in the bedroom, the more distant or smaller is the students' personal space (Cozby, 1973). From preference's analysis, student choose larger dimension of bedrooms with a small number of occupants (bedroom dimension of $10 \times 10 \mathrm{~m}, 7 \times 7 \mathrm{~m}$ and $8 \times 8 \mathrm{~m}$ ). The preferred number of occupants is 4-10 people. Likewise Susilawati's study in Wulandari (2016), she has identified that the students prefer a room for two people. Therefore, less occupier density and crowding in the bedroom are preferred by students.

Choosing bedroom's dimension and number of occupants, the students ignore the factor of price or the cost of tuition fee. This result is in line to the study of bedroom attribute preference by Oppewal et al. (2005); which states that the students do not fully account the price/cost when ranking the preferences. As the result, the indicated ratings are based on the physical quality or condition of bedroom, rather than its price/cost.

Based on students' preference, bedroom dimension is $10 \mathrm{~m}^{2}$, while in the existing (PPSD) is only 1,2-1,5 $\mathrm{m}^{2}$. Thus, the level of satisfaction of student is very low. The adaptation efforts are done by adjustment and by withdrawal. Adaptation by adjustment is performed when students sleep in an area only $1.2 \mathrm{~m}^{2}$ to $1.8 \mathrm{~m}^{2}$, along with the bedroom furniture. Hence, they use large carpet as sleeping mattress for two or more students. Adaptation by withdrawal is done by student, if the room is too crowded, they prefer to sleep outside the bedroom, i.e., corridor (figure 14).

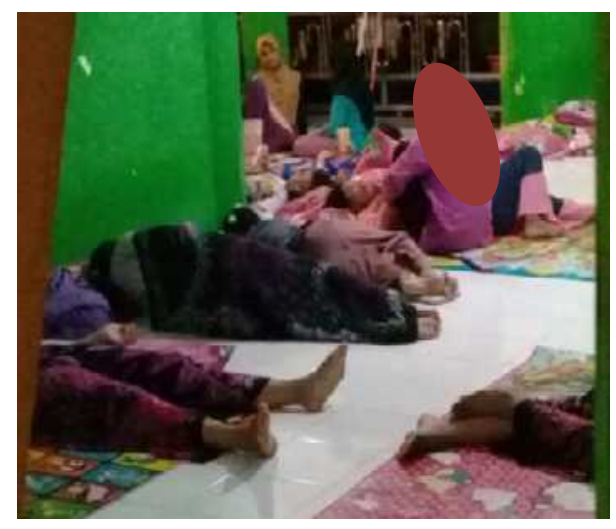

Figure 14. Sleep Outside Bedroom

Source: Author Documentation, 2018 


\section{d. Type of Bedroom Occupants}

Based on students' preference, they are more comfortable to live with the same grade, department or interest in the same dormitory's bedroom. The students are less favoured if the member of dormitory's bedroom is mixed with different grade level or interest. It indicates that the factor of closeness, similar motivation and interest are considered important for choosing the group members. The result is in line with what other researchers stated that human tends to live with similar background of social level, interest, age, etc. (Little, 1974; Kirwan \& Ball, 1974 in Rahma, 2010); Bennett (1974); and Rowland (1998). In PPSD, the bedroom occupant is determined by students' grade and interest. Thus, the level of students' preferences is high with lower adaptation efforts.

\section{e. The Summary of Preference and Adaptation Analysis}

The analysis summary of the preference and adaptation can be seen in table 3 .

\section{The Concept of Bedroom Size}

After defining students' preference in dormitory's bedroom, the concept of pesantren's bedroom is proposed by highlighting the aspects of student's activity, privacy, security, territory, personal space, crowding and density, closeness with other occupant, cleanliness, and position of door and window. The concept is focused on the dimension needs of bedroom area per person with considering students' belongings and furniture arrangement.

\section{a. The Formulation of Space Area per Person}

Determining the bedroom area per person is based on students' preference with considering students' belonging and its furniture. The size of furniture is taken from the largest typology existed in the type B non-affiliated organization pesantren. The calculation of bedroom area per person is explained in Table 4. 
Table 3. The Summary of Preference and Adaptation Analysis

\begin{tabular}{|c|c|c|c|c|c|c|}
\hline Bedroom need & Typology & Preference & $\begin{array}{c}\text { Aspect that } \\
\text { effect }\end{array}$ & Evaluation & Adaptation & $\begin{array}{c}\text { Student want on bedroom } \\
\text { facility }\end{array}$ \\
\hline $\begin{array}{l}\text { Placement of } \\
\text { furniture and tool }\end{array}$ & $\begin{array}{l}\text { Type A } \\
\text { Type B }\end{array}$ & Type A & $\begin{array}{l}\text { - Privacy } \\
\text { - Security }\end{array}$ & +++ & o & $\begin{array}{l}\text { Student wants territory } \\
\text { - Student wants security for } \\
\text { personal items }\end{array}$ \\
\hline Interior arrangement & $\begin{array}{l}\text { Type } 1 \\
\text { Type } 2\end{array}$ & Type 1 & $\begin{array}{l}\text { - Cleanliness } \\
\text { - Door and } \\
\text { window } \\
\text { position }\end{array}$ & ++ & $\bullet$ & $\begin{array}{l}\text { - Student wants visual comfort } \\
\text { of cleanliness }\end{array}$ \\
\hline Bedroom size & $\begin{array}{l}3 \times 3 \text { m until } 10 \times 10 \\
m\end{array}$ & $\begin{array}{l}10 \times 10 \mathrm{~m} \\
8 \times 8 \mathrm{~m}, 7 \times 7 \mathrm{~m}\end{array}$ & $\begin{array}{l}\text { - Personal } \\
\text { space }\end{array}$ & + & $=0$ & $\begin{array}{l}\text { - Student wants high personal } \\
\text { space }\end{array}$ \\
\hline $\begin{array}{l}\text { Number } \\
\text { occupants }\end{array}$ & $4-50$ students & 4-10 students & $\begin{array}{l}\text { - Crowding } \\
\text { and density }\end{array}$ & + & & $\begin{array}{l}\text { Student wants their personal } \\
\text { activities to be accommodated }\end{array}$ \\
\hline Area/student & & $10 \mathrm{~m}^{2}$ & & + & & in the room \\
\hline Type of occupant & $\begin{array}{l}\text { - School level } \\
\text { - Grade level } \\
\text { - Major } \\
\text { - Interest } \\
\text { - Mixture }\end{array}$ & $\begin{array}{l}\text { - School } \\
\text { level } \\
\text { - Grade } \\
\text { level } \\
\text { - Major } \\
\text {. Interest } \\
\end{array}$ & $\begin{array}{l}\text { - Same } \\
\text { motivation } \\
\text { and interest }\end{array}$ & +++ & - & $\begin{array}{l}\text { Student wants closeness with } \\
\text { bedroom members } \\
\text { - Student wants to be able to } \\
\text { discuss school subjects or } \\
\text { areas of specialization with } \\
\text { the same person }\end{array}$ \\
\hline
\end{tabular}

Note:

$\begin{array}{llll}- & \text { : By reaction } & ++ & \text { : Very suitable } \\ \circ & \text { : By adjustment } & ++ & \text { : Suitable } \\ \text { - } & \text { :By withdrawal } & + & \text { : Not suitable } \\ \square & \text { : By giving up } & - & \text { : Nothing }\end{array}$


Table 4. The Student Need of Students' Belonging

\begin{tabular}{|c|c|c|c|c|}
\hline \multirow{7}{*}{ Activity } & Need & Furniture & Dimension & $\begin{array}{l}\text { Bedroom area } \\
\text { per person }\end{array}$ \\
\hline & $\begin{array}{l}\text { Clothes } 5 \text { set } \\
\text { Uniform } 5 \text { set } \\
\text { Mukenah } \\
\text { Towel } \\
\text { Underwear } \\
\text { Books, Al-Qur'an and } \\
\text { stationery } \\
\text { Drugs and Cosmetics }\end{array}$ & Cupboard & $0.6 \times 0.6 \times 1 \mathrm{~m}$ & $0.36 \mathrm{~m}^{2}$ \\
\hline & $\begin{array}{l}\text { Another tool } \\
\text { Mattress }\end{array}$ & $\begin{array}{l}\text { Suitcase } \\
\text { Mattress } \\
\text { when } \\
\text { folded }\end{array}$ & $\begin{array}{l}0.34 \times 0.49 \times 0.22 \mathrm{~m} \\
0.5 \times 0.9 \mathrm{~m}\end{array}$ & $\begin{array}{l}0.17 \mathrm{~m}^{2} \\
0.45 \mathrm{~m}^{2}\end{array}$ \\
\hline & $\begin{array}{l}\text { Pillow } \\
\text { Shoes and sandal } \\
\text { Bucket }\end{array}$ & Lockers & $\begin{array}{l}0.51 \times 0.75 \mathrm{~m} \\
0.3 \times 0.3 \times 0.5 \mathrm{~m} \\
0.67 \times 0.67 \times 0.28 \\
\mathrm{~m}\end{array}$ & $\begin{array}{l}0.39 \mathrm{~m}^{2} \\
0.09 \mathrm{~m}^{2} \\
0.45 \mathrm{~m}^{2}\end{array}$ \\
\hline & $\begin{array}{l}\text { Bath tool } \\
\text { Bag } \\
\text { Clothes hanger }\end{array}$ & Lockers & $\begin{array}{l}0.3 \times 0.3 \times 0.5 \mathrm{~m} \\
0.45 \times 0.3 \times 0.15 \mathrm{~m} \\
0.4 \times 0.1 \mathrm{~m} \times 12 \\
\text { pairs }\end{array}$ & $\begin{array}{l}0.09 \mathrm{~m}^{2} \\
0.135 \mathrm{~m}^{2} \\
0.48 \mathrm{~m}^{2}\end{array}$ \\
\hline & Sleep, eat, study & $\begin{array}{l}\text { Mattress } \\
\text { when } \\
\text { used }\end{array}$ & $2 \times 0.8 \mathrm{~m}$ & $1.6 \mathrm{~m}^{2}$ \\
\hline & Bedroom area per person & & & $2.775 \mathrm{~m}^{2} / 2.8 \mathrm{~m}^{2}$ \\
\hline
\end{tabular}

\section{b. Furniture and Students' Belonging Arrangement}

After determining the area per person of bedroom, this calculation is not directly used to calculate the bedroom dimension. The reason is the bedroom dimension must consider the students' belongings which are placed and arranged communally. Besides, some furniture including tableware and trash bin are placed inside the dormitory's bedroom. Bedroom's wardrobes are explained as follows:
a. Cupboard
: $0.36 \mathrm{~m}^{2} / 2$ people
b. Mattress arrangement
: $0.45 \mathrm{~m}^{2} /$ Bedroom
c. Pillow arrangement
: $0.39 \mathrm{~m}^{2} /$ Bedroom
d. Suitcase arrangement
: $0.17 \mathrm{~m}^{2} / 5$ people
e. Shoes and sandal arrangement
: $0.09 \mathrm{~m}^{2} / 5$ people
f. Bath tool arrangement
: $0.09 \mathrm{~m}^{2} / 5$ people
g. Bag arrangement
: $0.135 \mathrm{~m}^{2} /$ room
h. Bucket arrangement
: $0.45 \mathrm{~m}^{2} /$ room
i. Sleeping area
: $1.6 \mathrm{~m}^{2} /$ people
j. Clothes hanger arrangement
: $0.48 \mathrm{~m}^{2} /$ people
k. Tableware
: $0.36 \mathrm{~m}^{2} /$ room 
1. Trash bin

m. Door
$: 0.189 \mathrm{~m}^{2} /$ room

: $0.64 \mathrm{~m}^{2} /$ Bedroom

Because of limited space and area, furniture and students' belongings arrangement are designed vertically and horizontally. Vertical arrangements (Figure 15) include cupboard, mattresses, pillows, suitcase, shoes/ sandals, bath tool, bags and bucket. The horizontal arrangement (Figure 16) is only for hanging space for clothes and sleeping areas. In addition, an area is provided to accommodate other items such as trash bins, dining cupboard, and placing the doors (Figure 15).

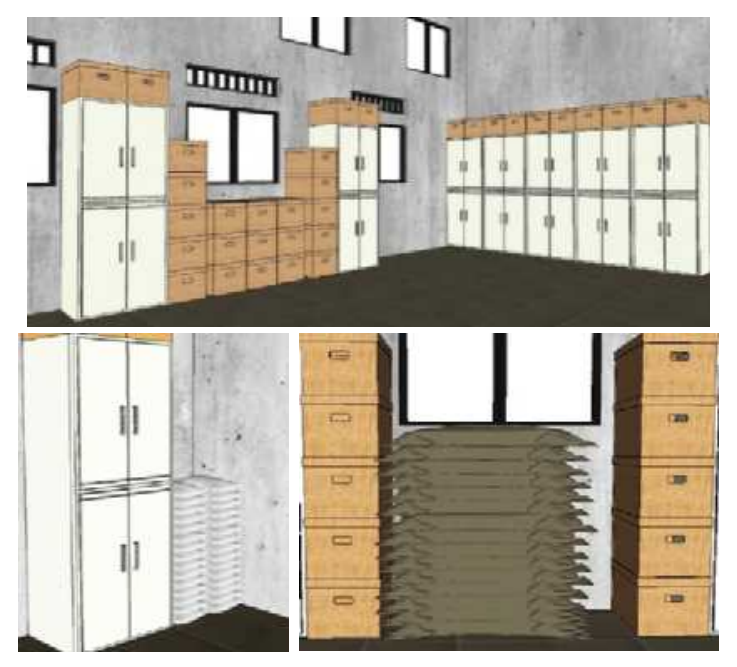

Figure 15. Vertical Arrangement Source: Author, 2018

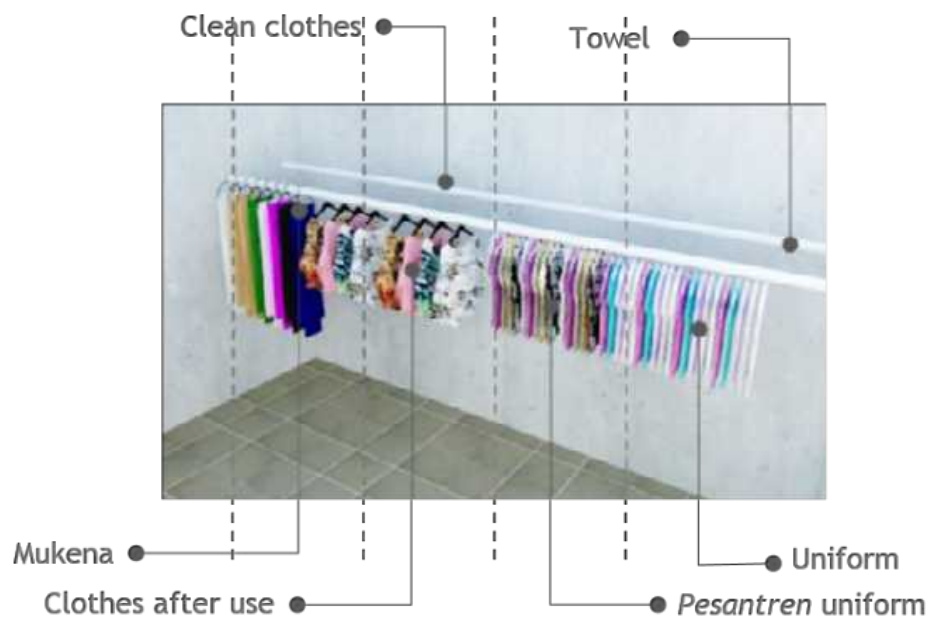

Figure 16. Horizontal Arrangement Source: Author, 2018 


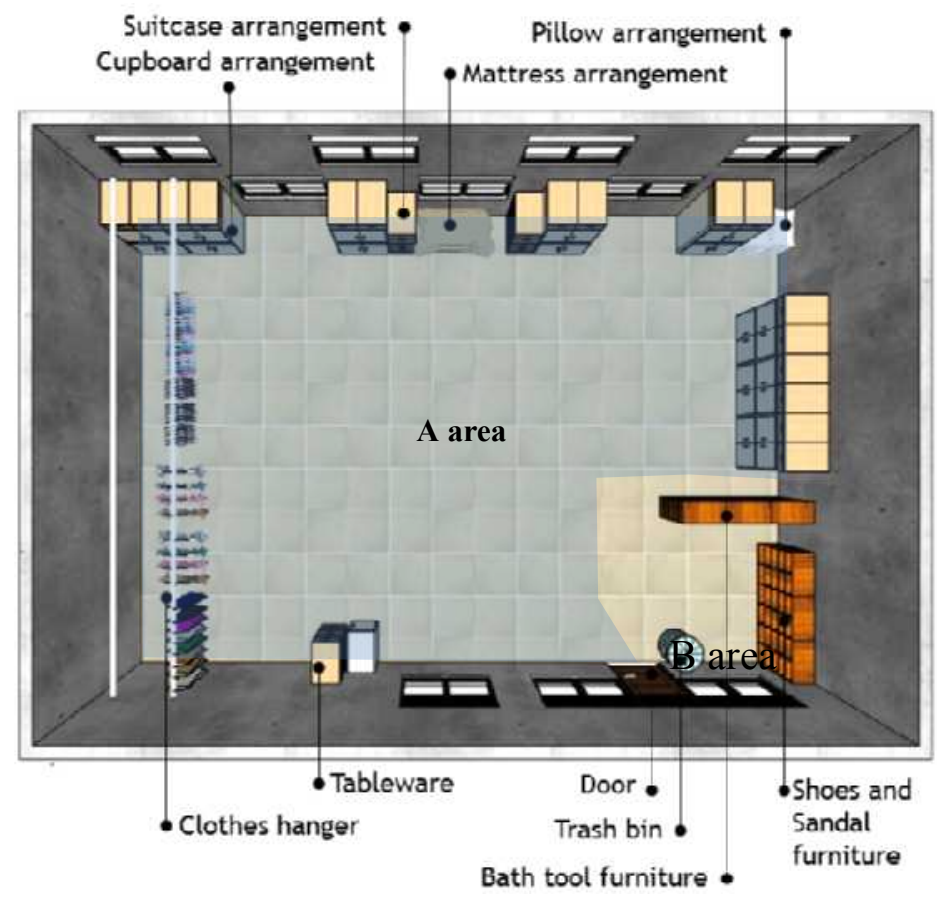

Figure 17. Furniture Arrangement

Source: Author, 2018

\section{c. Furniture Arrangement and Use Space}

The furniture arrangement is placed whether it is place in clean and sacred area (A) or in dirty and wet area (B) (see on Figure 17). Next, the use of space inside the dormitory's bedroom is determined. The Area of (A) is used for sleeping and the area of (B) is for furniture that is used communally by all students. Those areas are explained as follows:

(A) area: cupboard, mattress, pillow, sleeping area, suitcase, bag, clothes hangers, cutlery, door.

- (B) area: Trash bin, bucket, bath tool, cleaning tool, shoes and sandal.

Furniture arrangement is influenced by students' preference of its placement. Previously, the analysis shows that students prefer to keep their belongings inside the bedroom. Therefore, the design concept proposed is based on their preference by placing all goods and students' belonging inside the bedroom.

\section{d. Bedroom Dimension based on Number of Occupants}

The bedroom dimension is determined after furniture arrangement and bedroom's use of space are proposed. The ideal calculation of ideal bedroom based on the number of occupants (Table 5). 
Yusuf, Hayati, Faqih: THE CONCEPT OF FEMALE DORMITORY BEDROOM BASED ON STUDENTS' PREFERENCE AND ADAPTATION

Table 5. The Bedroom Dimension Formulation Based on the Number of Occupants

\begin{tabular}{|c|c|c|c|c|c|c|c|c|c|c|c|c|c|}
\hline & \multirow[b]{2}{*}{ Furniture } & \multirow[b]{2}{*}{ Size } & \multicolumn{11}{|c|}{ Number of Occupants (person) } \\
\hline & & & 3 & 5 & 10 & 15 & 20 & 25 & 30 & 35 & 40 & 45 & 50 \\
\hline \multirow{8}{*}{ 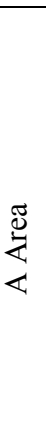 } & Cupboard & $0.72 \mathrm{~m}^{2} / 4$ people & 0.72 & 1.44 & 2.16 & 2.88 & 3.6 & 5.04 & 5.76 & 6.48 & 7.2 & 8.64 & 9.36 \\
\hline & Mattress arrangement & $0.45 \mathrm{~m}^{2} / 10$ people & 0.45 & 0.45 & 0.45 & 0.9 & 0.9 & 1.35 & 1.35 & 1.8 & 1.8 & 2.25 & 2.25 \\
\hline & Pillow arrangement & $0.39 \mathrm{~m}^{2} / 15$ people & 0.39 & 0.39 & 0.39 & 0.39 & 0.78 & 0.78 & 0.78 & 1.17 & 1.17 & 1.17 & 1.56 \\
\hline & Suitcase arrangement & $0.17 \mathrm{~m}^{2} / 5$ people & 0.17 & 0.17 & 0.34 & 0.51 & 0.68 & 0.85 & 1.02 & 1.19 & 1.36 & 1.53 & 1.7 \\
\hline & Bag arrangement & $0.135 \mathrm{~m}^{2} /$ bedroom & 0.135 & 0.135 & 0.135 & 0.135 & 0.135 & 0.135 & 0.135 & 0.135 & 0.135 & 0.135 & 0.135 \\
\hline & Sleeping area & $1.6 \mathrm{~m}^{2} /$ people & 4.8 & 8 & 16 & 24 & 32 & 40 & 48 & 56 & 64 & 72 & 80 \\
\hline & Clothes hanger & $0.48 \mathrm{~m}^{2} /$ people & 1.44 & 2.4 & 4.8 & 7.2 & 9.6 & 12 & 14.4 & 16.8 & 19.2 & 21.6 & 24 \\
\hline & Cupboard & $0.36 \mathrm{~m}^{2} /$ bedroom & 0.36 & 0.36 & 0.36 & 0.36 & 0.36 & 0.36 & 0.36 & 0.36 & 0.36 & 0.36 & 0.36 \\
\hline \multirow{7}{*}{ 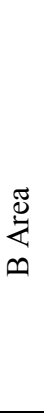 } & Door & $0.64 \mathrm{~m}^{2} /$ bedroom & 0.64 & 0.64 & 0.64 & 0.64 & 0.64 & 0.64 & 0.64 & 0.64 & 0.64 & 0.64 & 0.64 \\
\hline & $\begin{array}{l}\text { Shoes and sandal } \\
\text { arrangement }\end{array}$ & $0.09 \mathrm{~m}^{2} / 5$ people & 0.09 & 0.09 & 0.18 & 0.27 & 0.36 & 0.45 & 0.54 & 0.63 & 0.72 & 0.81 & 0.9 \\
\hline & Bath tool arrangement & $0.09 \mathrm{~m}^{2} / 5$ people & 0.09 & 0.09 & 0.18 & 0.27 & 0.36 & 0.45 & 0.54 & 0.63 & 0.72 & 0.81 & 0.9 \\
\hline & Bucket & $\begin{array}{l}0.45 \mathrm{~m}^{2} / 10 \\
\text { buckets }\end{array}$ & 0.45 & 0.45 & 0.45 & 0.9 & 0.9 & 1.35 & 1.35 & 1.8 & 1.8 & 2.25 & 2.25 \\
\hline & Trash bin & $0.189 \mathrm{~m}^{2} /$ bedroom & 0.189 & 0.189 & 0.189 & 0.189 & 0.189 & 0.189 & 0.189 & 0.189 & 0.189 & 0.189 & 0.189 \\
\hline & Cleaning tools & $0.36 \mathrm{~m}^{2} /$ bedroom & 0.36 & 0.36 & 0.36 & 0.36 & 0.36 & 0.36 & 0.36 & 0.36 & 0.36 & 0.36 & 0.36 \\
\hline & Use space & $\mathrm{B}$ area size/ 2 & 0.6 & 0.6 & 0.67 & 0.99 & 1.08 & 1.39 & 1.48 & 1.8 & 1.89 & 2.2 & 2.29 \\
\hline \multicolumn{3}{|c|}{ Bedroom size } & 10.884 & 15.764 & 27.304 & 39.994 & 51.944 & 65.344 & 76.904 & 89.984 & 101.544 & 114.944 & 126.894 \\
\hline
\end{tabular}


Based on the number of occupants, the bedroom is classified into five types (table 6), which are small, small-medium, medium, large, and extra-large bedroom.

Table 6. Bedroom Size Typology

\begin{tabular}{lcc}
\hline \multicolumn{1}{c}{ Bedroom type } & Wide & Number of occupants \\
\hline Small & $11-25 \mathrm{~m}^{2}$ & $3-<10$ people \\
Small to Medium & $26-45 \mathrm{~m}^{2}$ & $10-<20$ people \\
Medium & $46-75 \mathrm{~m}^{2}$ & $20-30$ people \\
Large & $76-100 \mathrm{~m}^{2}$ & $31-40$ people \\
Extra large & $101-120 \mathrm{~m}^{2}$ & $41-50$ people \\
\hline \multicolumn{3}{c}{} \\
\end{tabular}

\section{The New Concept of Bedroom Dormitory (Mezzanine)}

By considering the minimum area and bedroom dimension, the design concept proposes providing mezzanine inside the bedroom. This type of bedroom is considered as the optimum or generous type. Mezzanine is placed inside the bedroom only suggested in one or two sides of wall for providing good air circulation. In the mezzanine bedroom, the students can sleep and store their belongings only for the lightweight items such as pillows, bolsters or mattresses (Figure 19b).
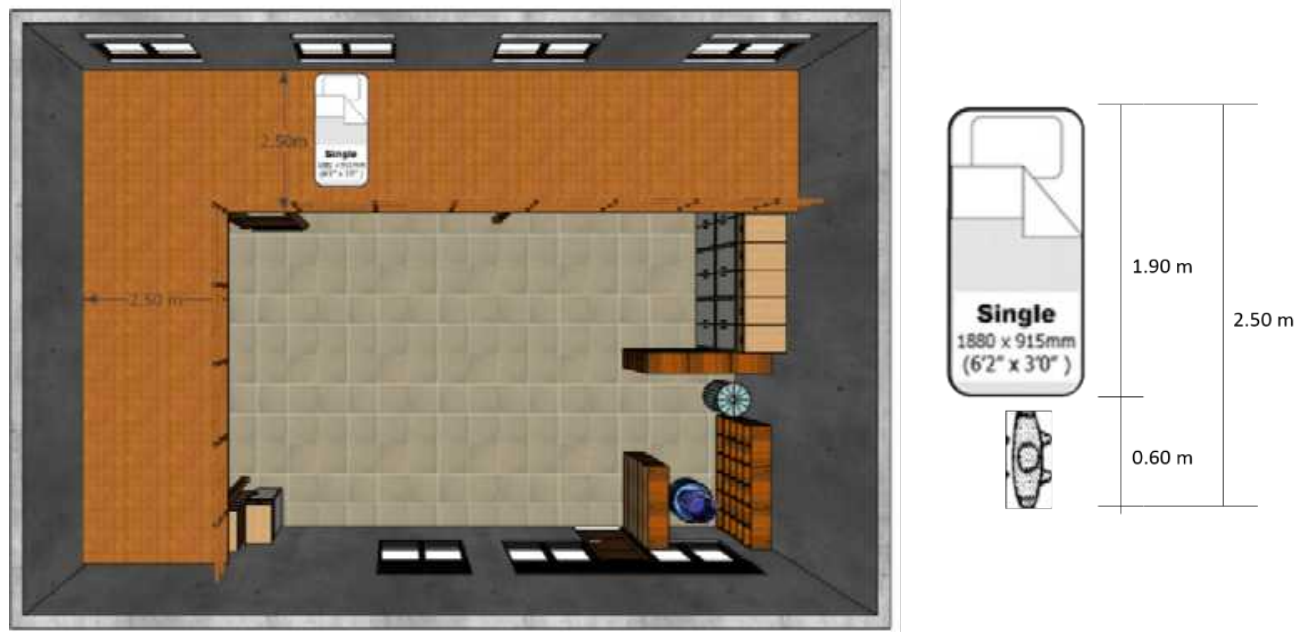

Figure 18. Mezzanine Room Source: Author Analysis, 2018 


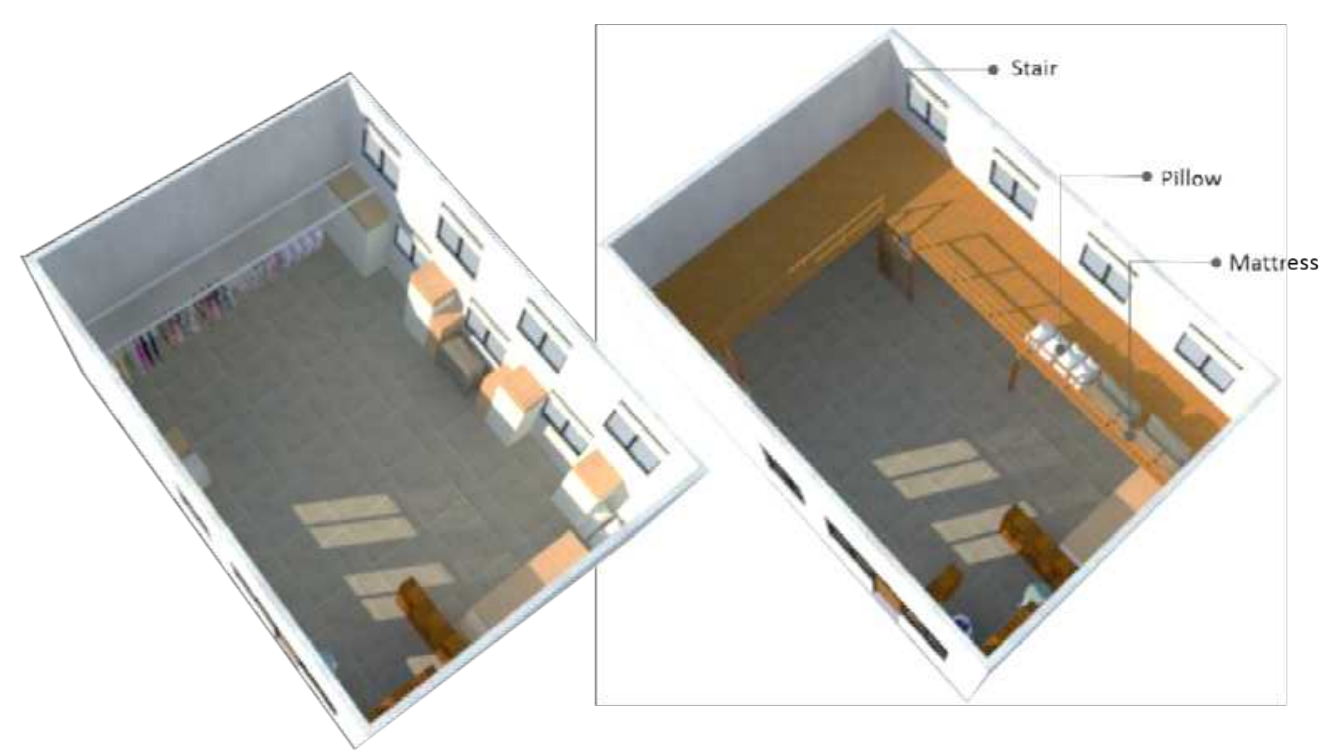

(a) Bottom level

(b) Mezzanine level

Figure 19. The Level of Mezzanine Room Source: Author Analysis, 2018

Designing mezzanine inside the bedrooms considers aspects as follows:

a. The Height of Bedroom's Ceiling

The recommendation of bedroom ceiling height is 5 meters (Figure 20). It is intended to design the mezzanine which is 2,8 meters from floor and 2,2 meters from upper level/ceiling (Figure 21).

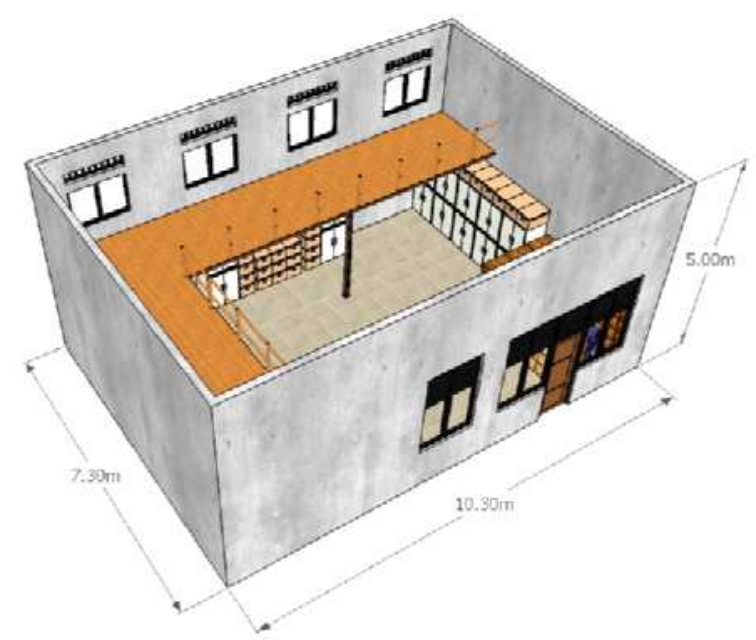

Figure 20. The Height of Mezzanine Room

Source: Author Analysis, 2018 


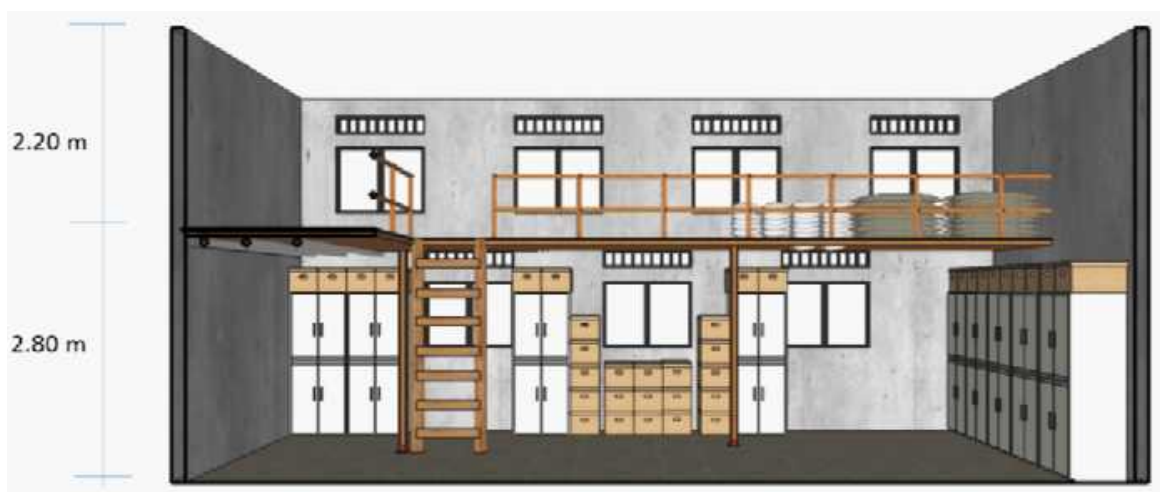

Figure 21. The Dimension of Mezzanine Room Height Source: Author Analysis, 2018

b. Bedroom's Window

The window placement is important to anticipate where the mezzanine is installed in order to provide good air circulation. If the mezzanine is added inside the bedroom, the window will be placed at the upper bench of mezzanine (Figure 22)

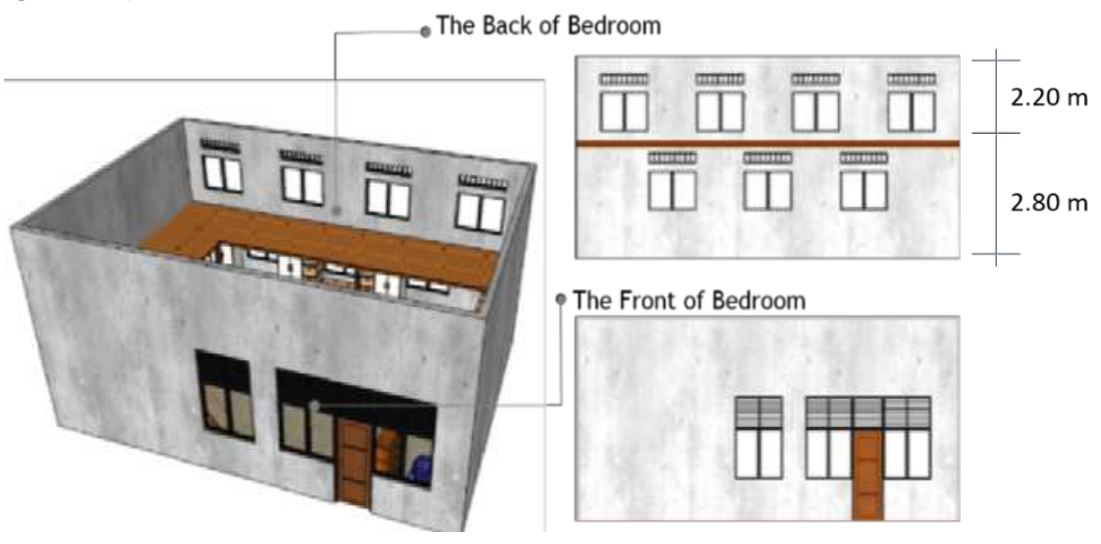

Figure 22. The Window of Mezzanine Room Source: Author Analysis, 2018

\section{CONCLUSION}

Bedroom is the smallest environment for students' activities. However, bedrooms in type B non-affiliated organization pesantren have insufficient facilities and high density of occupant. Thus, the student does adaptation to survive in pesantren. Most of bedroom standard in theory cannot be found in this pesantren. Therefore, the typology is derived from observation result in six pesantrens.

The typology in aspect of furniture and students' belonging is found based on placement of furniture and students' belongings and interior arrangement. In 
placement of furniture and students' belonging, there are (a) type a, all students' belongings are located in bedroom; and (b) type b, students' belonging that is dirty, wet and unclean is located outside bedroom. There are two type of interior arrangement, among them (a) type $1 /$ there is a physical limit between clean and dirty room; and (b) type $2 /$ there is not a physical limit.

The typology of bedroom size is found five type, it is very small, small, medium, large and extra-large. The aspect of bedroom area per person in the bedroom found the minimum type and below the minimum type. The number of occupants is found (a) 4-10 people; (b) 11-20 persons; (c) 21-30 persons; (d) 31-40 persons; and (e) 40-50 persons. The type of occupant is based on level of school, grade, major, interest and mixture.

The results of the preference show that students have a high preference for the aspect of the position of students' belonging placed in the bedroom, bedroom area per student $\left(10 \mathrm{~m}^{2}\right)$, and the type of similar members of bedroom. There are two aspects that affect student chooses preference, among others physiological and psychological aspect. Physiological aspect is thermal and visual comfort, while psychological aspect is motivation, security, privacy, personal space, territory, crowding and density. In relation to the conditions in the PPSD, aspect that has the highest suitability is the placement of students' belonging in the bedroom and similar with bedroom members. The bedroom size, bedroom area per person, and the number of occupants have a low level of conformity. Adaptations encountered in student's bedroom are adaptations by reaction, by adjustment, and by withdrawal.

Based on the issues above then the concept offered is the formulation concept of bedroom size and the new concept in the form of mezzanine bedroom. The formulation concept is done by formulating the minimum area per person first that is $2.8 \mathrm{~m}^{2}$. The bedroom area per person is done by calculating the student belonging and activity needs. Having known about students' belonging, next is arrangement of students' belonging and furniture that are arranged horizontally (clothes hanger and sleeping area) and vertically (cupboard, mattresses, pillows, suitcase, shoes/ sandals, bath tool, bags and bucket). Typology of bedroom size based on the number of occupants gets five types of them are small, small-medium, medium, large, and extra-large bedroom. To fulfil the student preference then can use the mezzanine concept.

\section{REFERENCES}

Arias, Ernesto. (1993). The Meaning and Use of Housing, Averbury, England.

Azzahro, Faizah Khoirunnisa. (2017) Perilaku Adaptasi Dan Adjustment Santriwati Pada Kamar Tidur Komplek RI Pesantren Al-Munawwir, Krapyak, Yogyakarta. Skripsi. Institut Seni Indonesia Yogyakarta. URL: http://digilib.isi.ac.id/2208/

Badri, M. (2007). Hygiene perseorangan santri pondok pesantren Walisongo. Media penelitian dan pengembangan kesehatan. Volume 17, no.2 Jun

Badri, (2008). Media Penelitian dan Pengembangan Kesehatan. Bandung. 
Bennet, D. C. (1974). Interracial Ratios and Proximity in Dormitories Attitudes of University Students. Environment and Behavior, Vol. 6 No. 2, June 1974. Sage Publications, 11 nc. URL: http://journals.sagepub.com/doi/abs/10.1177/001391657400600204?journalCod $\mathrm{e}=\mathrm{eaba}$

Bosworth, C.E., et.al, (1995), The Encyclopedia of Islam. New Edition. E.J. Brill, Leidn.

Chiara, J. D. and Callender, John. (1987). Time Saver Standar for Building Types 2nd Edition. McGraw-Hill Book Company. New York.

Cozby, Paul C. (1973) Effect of Density, Activity, and Personality on Environmental Preferences. Journal of Research in Personality 7, pp. 45-60. URL: https://www.sciencedirect.com/science/article/pii/0092656673900317

Dhofier, Zamakhsyari. (1994). Tradisi Pesantren: Studi Tentang Pandangan Hidup Kyai. LP3ES, Jakarta.

Fernawan, Niky Surya. (2008) Perbedaan Angka Kejadian Skabies di Kamar Padat dan Kamar Tidak Padat di Pondok Pesantren Modern Islam PPMI Assalaam Surakarta. Skripsi thesis, Universitas Muhammadiyah Surakarta. URL: http://eprints.ums.ac.id/4352/

High, T., dan Sundstrom, E. (1977). Room Flexibility and Space Use in a Dormitory. Environment and Behavior. Volume 9 No. 1, pp: 81-90

Miftahudin. (2011). Tipologi Pondok Pesantren dalam Konstelasi Pembaharuan Pendidikan Islam. Studi pada Pesantren-pesantren di Kabupaten Kudus. Skripsi. Faculty of Education. Walisongo state Islamic religious institute. URL: https://www.scribd.com/doc/59599964/Skripsi-Tipologi-Pondok-Pesantren

Ministri of Health Indonesia, (2007), Cegah dan Hilangkan Penyakit 'Khas' Pesantren. Jakarta.

Mu'in, Abdul, et.al. (2007). Survey Tipologi Pondok Pesantren Dalam Pemenuhan Pelayanan Pendidikan Keagamaan Bagi Masyarakat. Badan Litbang dan Diklat Kementrian Agama RI. URL: https://balitbangdiklat.kemenag.go.id/posting/read/858-postingreadsurveytipologi-pondok-pesantren-dalam-pemenuhan-pelayanan-pendidikankeagamaan-bagi-masyarakat.

Oppewal, H., Poria, Y., Ravenscroft, N., Speller, G. (2005) Student Preferences for University Accommodation: An Application of the Stated Preference Approach. Housing, Space and Quality of Life, Ricardo Garcia-Mira, David L.Uzzell, J. Eulogio Real and Jose Romay (Eds), Ashgate publishers, Gower House, Aldershot, Hampshire, UK, pp 113-124. URL: http://epubs.surrey.ac.uk/823771/

Prabowo, Hendro. (1998). Seri Diktat Kuliah arsitektur psikologi dan masyarakat. Gunadarma, Jakarta.

Radhi, M. (2010). Mekanisme Adaptasi dan Perubahan Komponen Ruang, Studi Sampel Ruang hunian dan Ruang Pendopo di Panti Wredha Budhi Dharma dan Hanna di Kota Yogyakarta. Universitas Gadjah Mada. Yogyakarta. URL: http://etd.repository.ugm.ac.id/index.php?mod=penelitian_detail\&sub=Penelitia nDetail\&act=view\&typ=html\&buku_id=46992

Rahma, ISZ. (2010). Analisis Faktor-Faktor Yang Mempengaruhi Permintaan 
Perumahan Tipe Cluster (Studi Kasus Perumahan Taman Sari) Di Kota Semarang. Skripsi. Diponegoro University, Faculty of Economy. Semarang. URL: http://eprints.undip.ac.id/23100/1/SKRIPSI.pdf

Rahmawati, Adelina.(2015) Hubungan Antara Efikasi Diri Dengan Penyesuaian Diri Santri Baru. Skripsi, Universitas Muhammadiyah Surakarta. URL: http://eprints.ums.ac.id/35428/

Rapoport, Amos. (2005) Culture, Architecture and Design. Lock Science Publishing Company. Chicago.

Rowland, Mary R.A. (1998) Using A Roommate Preference Survey For Students Living On An Engineering Dorm Floor. FIE Conference. URL: https://ieeexplore.ieee.org/document/736903/

Sopi'i. (2014). Pondok pesantren dan pendidikan politik (kajian historis di pondok pesantren al-ishlah kecamatan compreng kabupaten subang 1999-2014). Universitas Pendidikan Indonesia, Bandung. URL: https://core.ac.uk/download/pdf/144112412.pdf

Sudiarta, Nyoman I., (2016). Hubungan Manusia dengan Arsitektur. Departement of Architecture. Udayana University. URL: http://erepo.unud.ac.id/4436/1/db78a40029aef62f2cfbff500e4c02a4.pdf

Suryawan, (2013). Pola pendidikan akidah di pesantren dalam membentuk karakter santri. Thesis. Departemen of general education. Indonesian education university. Bandung. URL: https://core.ac.uk/download/pdf/144084959.pdf

Wahid, Abdurrahman. (2001). Menggerakkan Tradisi, esai-esai pesantren. LkiS: Yogyakarta

Wulandari, Ratri. (2016). Analisa Kaitan Desain Asrama Dengan Perilaku Penghuni Melalui Studi Analisa Konten Penelitian Sejenis. Jurnal IDEALOG, IDE DAN DIALOG INDONESIA Jurnal Desain Interior \& Desain Produk Vol.1 No.3, September 20. URL:

http://journals.telkomuniversity.ac.id/idealog/article/view/942

Yusuf, Mimin Aminah. (2018). Konsep Perancangan Asrama Putri di Pondok Pesantren Berbasis Preferensi dan Adaptasi. Unpublished Thesis. Department of Architecture. Institute Technology of Sepuluh Nopember. Surabaya.

Https://agtvnews.com/2017/04/pondok-pesantren-identik-dengankumuh.html. Last accessed at 12 Mei 2018

Http://portal.banyuwangikab.go.id/news/detail/1947/menepis-kesan-kumuhjorok-kumal-ponpes-nur-cahaya-masuk-final.html. Last accessed at 21 pebruari 2018 